\title{
農薬による自然環境污染とその対策
}

\author{
西島修 \\ 農林省農薬検査所 (東京都小平市鈴木町 2-772)
The Environmental Pollution by Pesticides and Counterplan

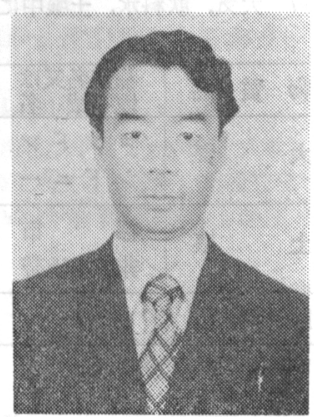

\section{Osamu Nishijima}

The Agricultural Chemicals Inspection Station (2-772, Suzuki-cho, Kodaira-shi, Tokyo)

\section{はじめに}

昭和 49 農薬年度（昭和 48 年 10 月 49 年 9 月）の農薬生 産額は 2,026 億円であった, 殺虫剂, 除草剂, 殺菌剂, 殺虫殺菌剂とも前年を大幅に上回り, 生産数量は全体で 74万 7 千 で前年に比べて約 30\% 近くの増加となって いる。現在登録を受けて市販されている農薬の銘柄は 約 4,500 件で約 330 の化合物が農薬として使用されてい る。減反等による水田作付面積の減少, 耕地利用率の低 下といら現象とは逆に農薬生産量が毎年増え続ける現象 はどのように理解すべきであろうか。いろいろなところ で農薬問題がとりあげられ，多くの議論がなされてきて いる。そして，現在の農業技術を根本から見直そうとい う思想のもとで自然農法, 有機農法などについても多く の議論とそして実践が行われてきている。農薬につい て, 今までにわかってきた事の一端を記して今後の参考 に供したいと思う。

\section{1 農薬の出現}

薬剂が植物の病気の防除に大きな効果のあることを確 認したのはボルドー液の発明である。1879年から数年間 フランスのブドウ園ではブドウのベト病が大発生し, ブ ドウ生産が危機に陥った。ボルドー大学のミヤルデ教授 はボルドー地方で道路に面したブドウはこの病気にかか っていないことに気付き, 調べたところ, この地方では 盗難を防ぐために道路に面したブドウに石炭乳と銅塩の 混合液を散布する習慣のあることがわかった。これが心゙ 卜病を防いでいることに気付き, 石炭乳と硫酸銅との混 合を系統的に研究してついにボルドー液を開発したので ある。ボルドー液は他の化合物のどれよりもべト病に効 果があり，ブドウだけでなく，ジャガイモ疫病やトマト， リンゴ，バラなざの病気にも良く効いたのである。この ボルドー液がわが国に初めて持ち込まれたのは, 明治30 年代以降で, 当時ウドンコ病の流行に悩まされていた山
梨県下のブドウ園の危機を見事に救った。また，初期に 使用された殺虫㓮としては, アメリカで, ジャガイモの 害虫として猛威をふるったコロラドハムシに対するパリ スグリーン(硫酸銅水溶液に亜ヒ酸ナトリウム水溶液を 加え，これに酢酸ナトリウム希釈液を加えてつくる) や 七酸鉛（いずれも消化中毒剂）などがある。一方天然殺 虫片としては, 1800年ころトランスコーカサス地方で除 虫菊が使用されている。この殺虫成分はピレトリンと呼 ばれる複雑な化合物である。タバコは除虫菊よりもやや 古く, 1763年ころフランスで殺虫㓮として使ったといら 記録荗ある。タバコの殺虫成分恃有名なニコチンであ る。熱帯汇分布するマメ科植物デリス・エクプティカの 根に殺虫成分ロテノンが含まれているが，1848年デリス の殺虫剂としての利用が発表されている。

このように第二次大戦前は七酸鉛, 七酸石炭などのヒ 酸塩類, 石炭硫黄合剤など数種の無機化合物 と, 除虫 菊, タバコ, デリスなど植物成分を原料とした殺虫剤し かなかった。BHC, DDT に代表される有機合成農薬が 使用されるようになったのは第 2 次大戦以後のことであ る。

わが国が敗戦の混乱から立ち直るためには, まず食糧 の確保が最も重要なことであった。そのためには肥料と 効果のある農薬が何よりも求斿れたわけである。その 当時衛生害虫駆除に用いられ始めていた DDT も早速農 薬として試験されることになった。各地の農業試験場で 各種害虫に試験した結果その強い殺虫力と適用害虫の広 さ，効力の持続性などを確認することができた。この目 を見張る効果は, 稲作の害虫防除のために水田に薬剤を 散布するなどといらことは，到底不可能であるといらそ れまでの既成概念をらちくずすことになった。1942年イ ギリスの ICI 社で BHC が，1934年ころからドイツの バイエル社でパラチオンなど一連の有機リン郕が，また アメリカのシェル社ではアルドリン，ディルドリンなど のシクロジエン殺虫剤が相次いで開発され，これらの強 


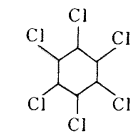

$\operatorname{BHC}(\alpha, \beta, \gamma, \grave{o}, \varepsilon)$
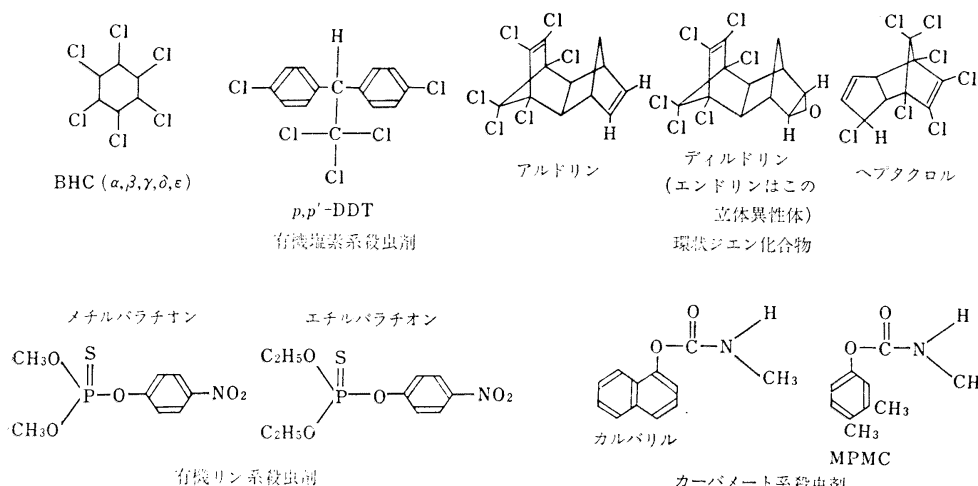

図-1 代表的農薬の棈造式

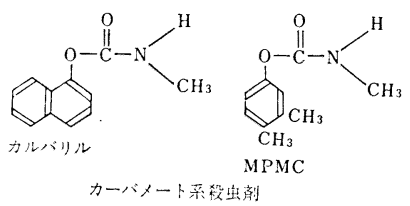

な病気の種類はイネ 25, オオムギ 30, ジャガイモ 19，トマト 26，キュウ リ16などである。このうち細菌は約 260 種であるが，今日知られる病原 となるカビは約 8,000 種に達してお り，カビによる病気が圧倒的に多い のが植物病害の特徵である。一方, 現在まで種として記載されているこ ん虫注約 90 万種といわれており，そ の中で害虫といわれるむのは讨界で 約 3 万種である。こん虫は植物を直 接食害するばかりでなく，植物の病 気を媒介して大きな被害を与光るも 力な殺虫剤は害虫防除に大きな役割を果たすことになっ た。そして各殺虫剤の特性により適用害虫が分化してい き, ニカメイガにはパラチオンと BHC, ウンカ, ヨコ バイ類にはマラソンなどの有機リン剂，コガネムシ，ヨ トウムシにはシクロジエン剂などというように害蚴除 すなわち殺虫剤散布といら状態汇なっていった。

パラチオンがわが国に紹介されたのは昭和 23 年であ り, 実際记試験されたの注和 26 年である。ホリドール 乳剂をニカメイチュウに試験したところ, 大変すばらし 殺蝴果を示した（ニカメイチュウは稲の葉しょう (鞘)や茎の中に食入するので，これを防除すること注大 変困難であるとされてい芯)。また果樹の害虫に対して もパラチオンはすぐれた効力を発揮した。しかし，パラ チオンは人畜に対してきわ的て強い急性毒性を有し, そ れを使用することは一面では命がけの作業であった。パ ラチオンが実用化された昭和27年は稲イモチ病の防除に セレサン石炭が使用された年でもあり，これが後に水銀 污染をもたらすことになるわけである。このように各種 の殺虫剤が開発され，その利用によって害虫を防除する ことができるといら前提化立って，早期栽培が行われ， また多肥栽培による多収穫栽培技術が奖励されたのであ る。このような栽培体系は寒泠地における冷害, 九州・ 四国地方汇扮汀る收穫期の台風被害をさけさせ, 食糧增 産を推進することとなった。しかし，一方このような栽 培体系は, イネを害虫の格好のえさ場として提供するこ とになり, 農薬による病害蚴除の必要性が増々执大し ていくことにつながっていくのである。

\section{2 作物と病害虫および雑草}

昭和 49 年度の米の収量は 1,229 万 2 千 $\mathrm{t}$ であったが, イモチ病やニカメイチュウ, ウンカなどによる病虫害, 天候不順による減収など全被害の総計は 111 万 $3915 \mathrm{t}$ に 達し, 収量の約 $9 \%$ にもなっている。このように病害虫 による被害もきわめて大きいわけであるが，作物は大低 10種以上の病気をもつといわれる。現在わかっている主

のもある。例えば，稲では，ツマグロヨコバイによって ウィルスが媒介されるい縮病や，ヒメトビウンカによっ てウィルスが媒介されるシマハガレ病などがある。い縮 病にかかった稻什伸長せず，ほとんど穗が出なくなって しまう。またシマ八ガレ病にかかると稲の葉が叔じ曲 り, やがて枯れていく。この他野菜や花にもウィルス病 が多く,アブラムシなどによって媒介される。

全世界には 20 万〜 30万種の高等植物が分布し，そのう ち雑草は 3 万種以上といわれている。日本では約 450 種 の耕地雑草が認められており, 水田に43科 191 種, 畑沉 53 科 302 種あり, そのうち水田雑草の $1 / 3$, 烟地雑草つ $1 / 2$ が多年性雑草である。そしてウリカワ，オモダカ， ミズガヤツリなどの多年性雑草が最近著しく增加してい る。

\section{3 農薬と生物相}

\section{1 病害虫の多発亡薬剤抵抗性}

農薬が初めて使われ始めたころは，目を見張るような 効果があったため, 農薬によって病害虫防除は簡単に行 われると考えられた。しかし，実際には農薬散布量は年 々増加の一途をたどっていったのである。なぜであろう か。その原因としては生態学的視野が根本的に欠除して いたからであるといってよいであろう。

殺虫剂に抵抗性の害虫が初的て報告されたのは, 1914 年カリフォルニア州でかんきつの害虫として被害を与え ていた, サンホーゼカイガラムシの石灰硫黄合剤抵抗性 である。しかし，そのころは殺虫剤の使用量がきわ的て少 なく,㐫まり問題にならなかった。Ripper ${ }^{1}$ はDDT など 有機合成農薬の登場後わずか10年間で農薬散布をしたた め, 世界では13科50種の害虫が異常発生したと報告して いる。農薬の散布によって防除を目的とした害虫ばかり でなく, その害虫の天敵あるいは害虫として重要な地位 を占めない潜在害虫の天敵をも殺して, これら潜在害虫 に新しく害虫としての地位を与えてしまったのである。 また Massee $^{2}$ によれば,イギリスのリンゴ園では殺虫 
表-1 水田において殺虫剂散布に伴い生息密度が著し く変わったと思われる主な種類*

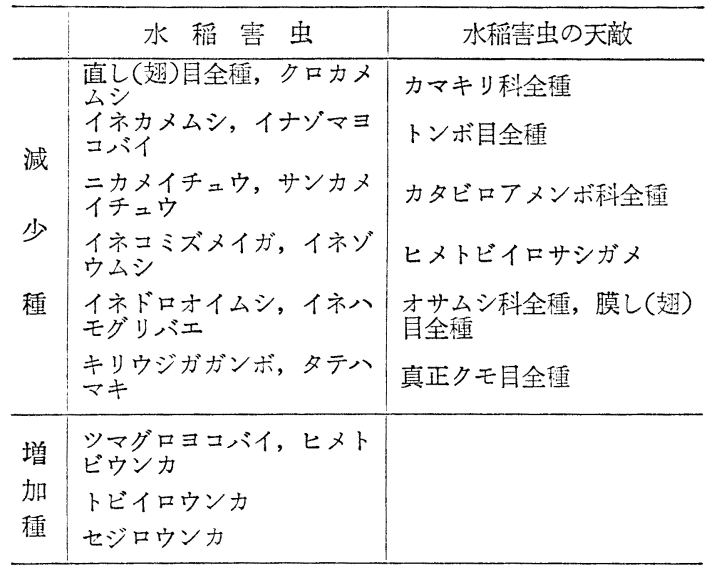

*大串龍一, “農薬なき農業は可能か”, 農山漁村出版協会 (1972) p. 96.

剂散布がせいぜい年 1 回以内であった1920年以前におい ては害虫も 60 種, 天敵は40種も生息していた。しかし, 戦後の DDT などの導入によってかつてリンゴ園にいた 天敵類のほとんどが姿を消し，わずか 4 種類が主要害虫 として残った。それにもかかわらずリンゴ園の虫害はそ の害虫の個体群密度が高いため, 数十年前の多数の害虫 によるよりもかえって大きくなったと報告されている。

1968年には世界で 224 種の害虫が各種の殺虫剂に抵抗 性を獲得したことが報告されている。また抵抗性獲得が 報告されている害虫の11例について新しい殺虫剤が使わ れ始めてからどの位で害虫が抵抗性を獲得したかを調べ た結果最低 2 年, 平均で 5 年で抵抗性を獲得している (桐谷, 川原 ${ }^{3}$, 1970) 殺虫阂の使用量の増加とともに, か えってその勢力を增している害虫に八ダニがある。八ダ 二類はわが国だけでも58種が知られており，このうち半 数近いものが園芸作物に寄生加害している。ハダニ類は 世代の交替が早く，その個体群が薬剂による淘汰をらけ る速度が早いうえに, 比較的行動範囲が狭いために近親 交配が行われやすいなど, 抵抗性を発達させやすい条件 を有している。ハダ二の被害は直接作物体の枯死や欠損 につながるものではなく, 汁液の吸収一クロロフィルの 滅少一減収, 品質低下といったいわ門接的なものであ る。従来八ダ二の防除注予防的な駆除に重点がおかれて いたため，いきおい薬剤の過剩散布になりやすく，この ことが抵抗性の発達を早める原因にもなったのであろ ら。八ダニの多くは施肥量の増加とともに繁殖力が増大 することも知られている。このようなことからハダニは 殺虫剂がつくり出した典型的な害虫であるといえる。

日本で水田害虫における抵抗性が問題になったのは昭 和35年パラチオン抵抗性ニカメイチュウである。パラチ オンに次いで BHC 抵抗性が問題となった。その後昭和
表-2 殺虫剂抵抗性をもつといわれる事例*

\begin{tabular}{|c|c|c|}
\hline & $\begin{array}{l}\text { 抵抗性をもった } \\
\text { 䖵 名 }\end{array}$ & ききめが落ちた薬剤名 \\
\hline $\begin{array}{l}\text { イ } \\
\text { ネ } \\
\text { の } \\
\text { 害 } \\
\text { 虫 }\end{array}$ & $\begin{array}{l}\text { ニカイメチュウ } \\
\text { ッマグロ コバイ } \\
\text { ヒメトビウンカ } \\
\text { イネドロオイムシ } \\
\text { イネハモグリバエ }\end{array}$ & $\begin{array}{l}\text { パラチオン, BHC, MEP } \\
\text { マラソンその他の有機リン剂, } \\
\text { NAC その他カーバメート郕 } \\
\text { BHC, マラソン, MTMC } \\
\text { BHC } \\
\text { BHC }\end{array}$ \\
\hline 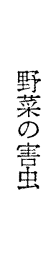 & 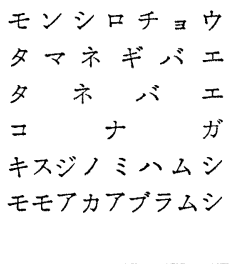 & $\begin{array}{l}\text { DDT } \\
\text { アルドリン, ヘプタクロル } \\
\text { アルドリン, ヘプタクロル } \\
\text { DDVP その他二, 三有機りン削 } \\
\text { アルドリン, ヘプタクロル } \\
\text { マラソン剂, ESP などニ, 三 有 } \\
\text { 機リン剂 }\end{array}$ \\
\hline
\end{tabular}

* 川井一之, 無農薬農業への挑戦と問題点, 遺伝, 5, 35 (1973)

表-3 薬戍耐性菌が問題になっている薬郕と乞の病害*

\begin{tabular}{|c|c|}
\hline 薬 & 病 \\
\hline ベノミル刘 (ベンレート) & キニウリうどんこ病 \\
\hline $\begin{array}{l}\text { チオフフォネトメチル剤 } \\
\text { (トップジンM) }\end{array}$ & リンゴ黒星病 \\
\hline チオファネート唷 (トップジン) & リリンゴうどんこ病 \\
\hline キノメチオネート剤（モレスタン） & メロンうどんこ病 \\
\hline $\begin{array}{c}\text { オキシカルボキシン郕 } \\
\text { (プラントバックス) }\end{array}$ & 蔽白さび病 \\
\hline カスガマイシン刘 (カスミン) & イネ いもち病 \\
\hline ポリオキシンBおよびL剂 & $\left\{\begin{array}{l}\text { ナシ黑斑病 } \\
\text { リンジ琹点落葉病 }\end{array}\right.$ \\
\hline ストレプトマイシン郕 & $\left\{\begin{array}{l}\text { タハバュ野火病 } \\
\text { 桑繀葉細菌病 }\end{array}\right.$ \\
\hline
\end{tabular}

* 植防コメント (1974-8-10), 日本植物防疫協会

36年にはツマグロヨコバイのマラソン抵抗性が報告さ れ，その後法各県で続々と薬㓮抵抗性害虫が発見されて いく。一方植物病原菌においても害虫同㥞に耐性菌の出 現が問題となっている。而性菌が問題となっている薬剤 の特徴としては，一般的に低毒性で，選択的な作用を有 することがあげられる。最近の選択的仁作用する薬剤の 增加々，長期連続使用が薬剤耐性菌の出現の原团になっ たと考えられる。

\section{2 天敵類に対する農薬の影響と天敵の保護}

大多数のこん虫はえさ不足になる程過密状態になる前 に自己調節機構が働いているらしい。これは密度が少し 高くなってくると成虫が卵を生まなくなったり，他の密 度の低い所へ移動していくことからうかがえる。従って 例えばツマグロヨコバイの平衡密紊は主にこのこん虫個 体群そのものに内在する自己調節機構によって決まって いるものと考えられる。ところがッマグロヨコバイの重 要な捕食天敵であるクモ類は 5 年間一切の農薬を散布し なかった実験田では, 当初株当たり 1 頭の密度から 5 年 目には23頭まで増加した。クモ類のほかにも卵寄生ばち の寄生率も年を追って高くなっている。そして 5 年間ク 
表-4 水田における殺虫剂無散布の期間とツマグロヨコ バイの天敵の增加の関係

\begin{tabular}{|c|c|c|c|c|c|}
\hline \multirow{2}{*}{ 年 次 } & \multirow{2}{*}{ 無散布 } & \multirow{2}{*}{$\begin{array}{l}\text { イネ株当た } \\
\text { りのピーク } \\
\text { 時のクモの } \\
\text { 個体数 }\end{array}$} & \multicolumn{3}{|c|}{$\begin{array}{l}\text { ツマグロヨコバイの涤世代の卯 } \\
\text { の卯寄生バチによる萃 }(\%)^{2)}\end{array}$} \\
\hline & & & 第 2 世代 & 第 3 世代 & 第 4 世代 \\
\hline 1968 & & 8 & 0.0 & 2 & 4.9 \\
\hline 1969 & & 2.5 & 1.2 & 51. & 51.5 \\
\hline 1970 & & 8.3 & 1.0 & 61.8 & 83.7 \\
\hline 1971 & 5 年目 & 22.9 & 16.3 & 73.0 & 80.1 \\
\hline
\end{tabular}

1）桐谷, 笹波(1972） 2) 笹波, 桐谷(1972)

* 桐谷圭治, 中筋房夫, 環境の科学, 日本放送出版協会 (1972) p. 261.

モ類が増え続けた実験田では，ツマグロヨコバイの卵密 度は 5 年前の $1 / 2$ 程度に減少している。また多数の二カ メイチュウの寄生ばちのうちズイムシアカタマゴバチの 寄生率を農薬使用時代以前と比較してみると, 戦前には かなり高い寄生率が見られていたが, BHCなどが使用さ 礼はじめると寄生率が極端に低下している。ツマグロヨ コバイは元来 BHC に対してあまり感受性が高くはなか ったので, 薬剤散布によって天䰻不在となった水田にお ける重要害虫となってきた。一方水田汇生息するクモの 種類は 13 科 170 種以上，そのうちごく普通にいるものは 8 科10種位である。これらクモ類のうちドクグモ類やセ スジアカムネグモ類はツマグロヨコバイを大変好み食じ の50〜75\%はツマグロヨコバイによって占められ，固場 に発生したツマグロヨコバイの幼虫の30～50\%，成虫の $50 \%$ 以上を捕食している。イネの収穫後 11 月末から 3 月 中旬にかけての調查で，無防除田の平均 $1 \mathrm{~m}^{2}$ 当たり 53 頭に対して防除田では22頭に半減していた。このような 薬阂散布の繰り返しのうちに水田からほとんどのクモ類 が姿を消していったのである。

八スモンヨトウの場合, 殺虫剤散布とともに, 良く除 草管理の行き届いた烟地条件も天敵相の貧困化（単一

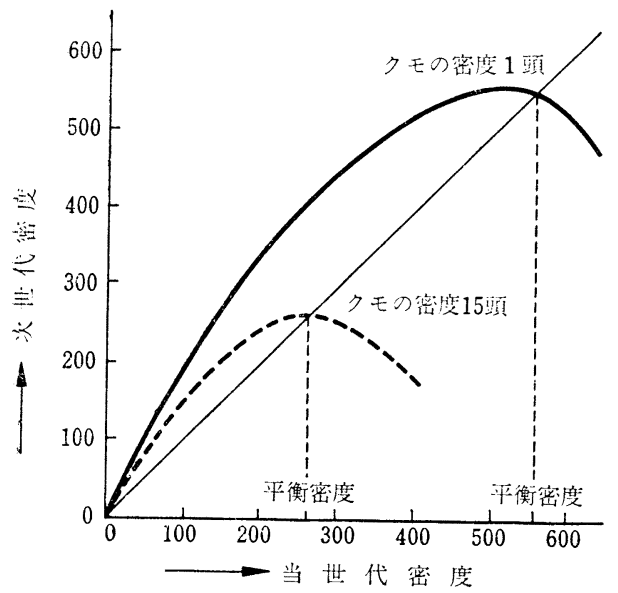

図-2 捕食性天敵のクモ類の密度がイネ株当たり 1 頭の ときと15頭のときのツマグロヨコバイ卵密度の増 殖曲線の比較
表-5 各理殺虫剤に対するツマグロヨコバイとクモ類の 感受性の比較(浸せき法による中央致死濃度ppm)*

\begin{tabular}{|c|c|c|c|c|}
\hline & & $\mid \begin{array}{l}\text { ツマグロヨ } \\
\exists \text { バイ }{ }^{1)}\end{array}$ & 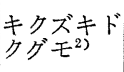 & $\begin{array}{l}\text { セスジアカ } \\
\text { ムネ゙グモ² }\end{array}$ \\
\hline \multirow{6}{*}{ カーバメー } & NAC & 132.5 & 59.1 & 1044.0 \\
\hline & BPMC & 176.1 & 253.4 & 4345.2 \\
\hline & MPMC & 176.1 & 70.7 & 650.0 \\
\hline & MTMC & 200.8 & 134.8 & 2481.2 \\
\hline & MIPC & 173.0 & 150.0 & 1532.8 \\
\hline & CPMC & 293.9 & 200.0 & 2044.1 \\
\hline \multirow[t]{3}{*}{ 有機リン系 } & マラソン & 735.0 & 500.0 & 2173.5 \\
\hline & ダイアジノン & 618.1 & 198.4 & 3220.2 \\
\hline & スミチオン & 6322.7 & 1782.1 & 3605.8 \\
\hline \multirow[t]{2}{*}{ 有機塩素系 } & DDT & 645.5 & 72.6 & 100.8 \\
\hline & BHC & 228.1 & 5.6 & 14.4 \\
\hline
\end{tabular}

1) 処理後 $6 \mathrm{hr}$ 経過の結果 2 ) 処理後 $24 \mathrm{hr}$ 経過の結果

* 川原幸雄, 桐谷圭治, 笹波隆文, 防虫科学, 36, 121(1971)

化）をもたらし，害虫化をひきおこした大きな要因にな っている。そこでハスモンヨトウのふ化幼虫集団を攻揧 して集団を分散させてしまらコサラグモ類と, 中老龄幼 虫を捕食するアシナガバチなどの重要な天敵功偟きやす い条件をつくってやれば，殺虫剤によらなくても多発を 防げる可能性がある。これまで雑草は作物の養分競合者 として考えられていたが，天敵類の保護地としての役割 も再評雨されなくてはならない。

\section{$3 \cdot 3$ 土壌生物および水中生物に及ぼす影響}

農薬はいったん土塞中に入った場合, 植物体上只土境 表層部と異なり，大変分解しにくくなる。土堙表面では $\gamma-\mathrm{BHC}$, ディルドリン, DDTのそれぞれの半減期が 5 , 9，18 週間であるのに対して，土塨中ではそれぞれ15〜 20週，4〜7年，5～8年と全くけた違いに長くなるのであ る。農薬の生物相への影響は農薬の毒性とその土壤中で の残留性の 2 つ要素で決まってくる。一般的にいって ミミズは他の土壤生物に比べて塩素系殺虫剤には強い。 ところがミミズは大量の土壌を体内を通過させるため， 土壌中濃度の 10 倍程度体内濃縮をおこすのでるる。

表-6 各種のミミズによる塩筀系殺虫戍の濃縮*

\begin{tabular}{|c|c|c|c|c|}
\hline \multirow{5}{*}{ ミミズの種類 } & \multicolumn{4}{|c|}{ 濃 縮 度 (倍) } \\
\hline & \multicolumn{4}{|c|}{ 殺 } \\
\hline & $\mathrm{D}$ 全 $\mathrm{T}$ & $\gamma-\mathrm{BHC}$ & $\begin{array}{l}\text { アルド } \\
\text { リン }\end{array}$ & $\begin{array}{l}\text { ディル } \\
\text { ドリン }\end{array}$ \\
\hline & \multicolumn{4}{|c|}{ 土䇏中濃度 (ppm) } \\
\hline & 0.93 & 0.004 & 0.72 & 0.64 \\
\hline L. terrestris (大型) & 1.18 & 1.5 & 0.069 & 2.5 \\
\hline A. louga (大型) & 1.43 & 1.5 & 0.39 & 3.44 \\
\hline O. oyaueum (大型) & 1.33 & 2.0 & 1.16 & 3.75 \\
\hline A. caliginosa (小型) & 2.68 & 2.75 & 0.72 & 5.9 \\
\hline A. chlorotica (小型) & 4.86 & 3.25 & 1.36 & 7.19 \\
\hline A. rosea (小型) & 2.78 & 4.25 & 0.88 & 6.09 \\
\hline
\end{tabular}

* G.A.Wheatley, J.A. Hardman, Nature, 207, 486(1968) 
ミミズの土壌中での働きをみてみると，一匹当たり一 年間に $0.8 \mathrm{~kg}$ といら大量の土境を処理しており，1 クタール当たり 3 万匹いると仮定すると， 1 年間 $25 \mathrm{t}$ の 土鎄を処理することになる。また採算牧草地での調査に よると $1 \mathrm{~m}^{2}$ 当たりに生息するミミズの平均重量は $44 \mathrm{~g}$ であり地表に運搬されるミミズのふん土は $1 \mathrm{~m}^{2}$ 当たり 年間 $16 \mathrm{t}$ となる。このようにミミズによって処理され る土の量漠大なものになる。ミミズは死ぬと自分のも つ消化液によって自己消化され，更に細菌や采状菌によ って分解される。このように土壌の粒団化を促進し，穴 掘作用によって上下の土層を反転させ，土の生産力を高 めるのに大きな役割を果たしているのである。しかし， 体内に大量の農薬を蓄積していることは，ミミズを捕食 する鳥類などによって更に高濃度に濃縮され，より一層 の污染をむたらすことになる。そしてまたカーバメート 剤のよらにミミズに対して毒性の高い農薬むあり, 近年 その使用量の増大とともに，農耕地におけるミミズの数 が減少してくることは，良好な土壤条件を維持していく

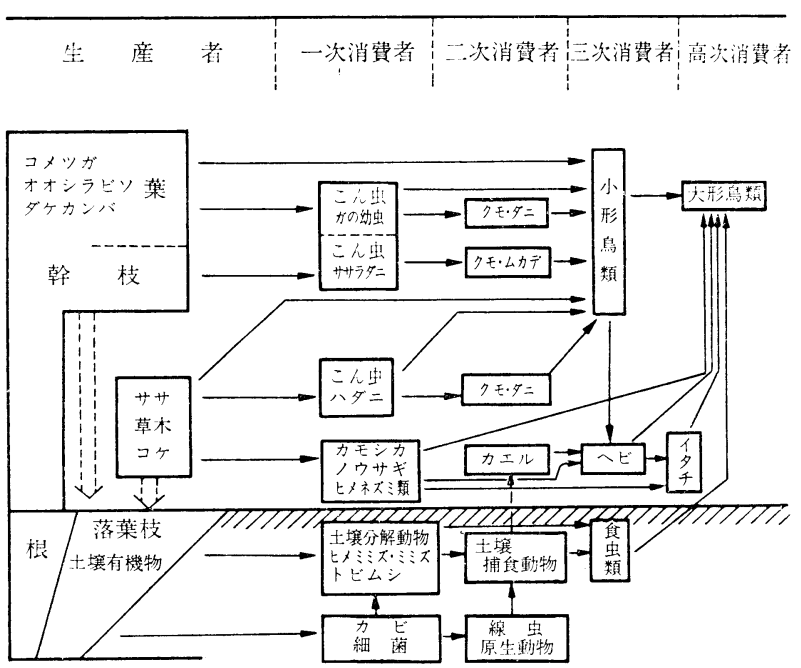

図-3 長野罢志賀山生態系の模式図（北沢右三による）

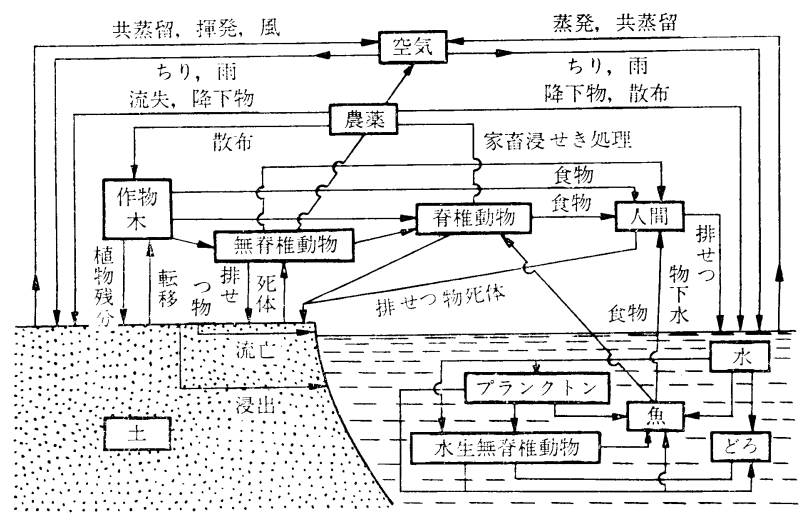

图-4 生態系における農薬の循環（エドワーズ，1969）
上においてきわめて重大な問題である。

次に水中生物に対する影響をみると, こん虫類ではト ンボやホタルは全生活環あるいはほとんどの期間を水中 生活する。これらは食肉性であることと相まって，エラ 呼吸によって農薬の体内濃縮が急速に行われやすいこと がその減少を招いた大きな原因と考えられる。一方力の ように幼虫は水中生活者でありながら空気呼吸をし，そ の発生回数も多いものでは水中での力の捕食虫が農薬に よって減少し，增殖に有利な条件となってくる。このこ とはカを媒介とする病気の多発につながることであり， 大きな問題である。

殺虫剤によって生物相が貧困化 (坚純化) されていく ことがわかっているが，このような現象は水中プランク トンなどにおいてもいえるようである。DDT によって 水中プランクトン相が乱され，その結果少数のプランク トンの異常増加により，水中溶存酸素の不足，あるいは プランクトンから分泌される毒素などによって，水中生 物が減少する可能性のあることが指摘されている。

魚類における生物濃縮の例としてホールデンの 実験がある。ディルドリンを $2.3 \mathrm{ppb}$ 含む水でニ ジマスを飼ったところ，約 3 週間でニジマスは死 亡した。死亡したニジマスのエラと肝臟からはそ れぞれ $18 \mathrm{ppm}$ と $16 \mathrm{ppm}$ のディルドリンが検出 された。つまりわずか 3 週間のうちに 8,000 倍近 い濃縮がおこったことになる。

このように土中，水中をとわず，污染物質がき わめて高度に濃縮されるということであり，希釈 すれば毒性が低くなるという安易な考え方が全く 成り立たないことを示している。污染物質が微量 であって直接生物の中毒死を起こさない量であれ ぼ，それだけ生態系内の食物連鎖を通じて，上位 生物へと濃縮が進んでいくことになる。

\section{4 環境の污染}

殺虫剂の施用法には大きく分けて, 害虫が食害 している作物に直接散布する方法と，水面あるい は土歵中に施用して作物体に吸収させ，あるいは 毛細管現象によって害虫に接触させる方法とがあ る。一般に直接散布された農薬のうち，作物体に 付着方量は, 作物の種類, 部位, 生育時期など によって異なるが，約 $10 \%$ 程度である。残りの 90\%近くが耕地への落下, 大気中への飛散, 土塆 水中に溶解して河川水への流入，水の蒸発にとも なわれての大気中への蒸散そして雨水に溶けて再 び地上に落下するなどのさまざまな過程を経て拡 散していく。

BHC は従来直接虫の体に接触して作用する殺 虫剂 (接触剂) であると考えられていたが，昭和 
30年ころ田植前の水田に BHC を施用してから苗を移植 すると，移植後の稻に産み付けられたニカメイチュウの 卵からかえった幼虫は葉しょう(鞘)に食入後死亡するこ とがわかった。これは BHCが根から吸収されて茥葉部 に移行するためである。この現象を防除に応用するため に, 従来の粉剂に代わって粒剂がつくられ，BHC 粒剤 の水面施用によるニカメイチュウ防除技術が確立された のである。これは当時使用されていた急性毒性のきわめ て強いパラチオンに代わるべきものが求市られていた時 だけに念速に普及していったが，粒剤化されて，濃度を 高くして使用したこととも相まって，日本の水田污染を 急激に進的ることにすなった。

さて, 世界的な規模で農薬の污染の状態が調査された 結果, 南極においても, 極地特産の魚から0.44 ppm、ア ザラシで $0.12 \mathrm{ppm}$ ，アデリーペンギンで $0.18 \mathrm{ppm}$, ト ウゾクカモメで $2.8 \mathrm{ppm}$ の DDT が検出された (George \& Frear $^{5)}$ 1966) この值はイギリス本国の野生動物に認 わられているDDT 残留の平均值とほぼ同じであって, DDT の污染が地球の極地まで達していることが確認さ れた。これは DDTが風によって運ばれたものであっ て，風による農薬の運搬が，世界的な規模での農薬污染 なもたらした因子として重視されている。

海洋交通しての污染の拡大も当然考えられ, 特にタン カーの洗浄等によって廃出される大量つ重油に辰薬が渹 解して拡散していくことが考えられる。

大気中の農薬については調査例はあまり多くないが, 普段は農村部よりも都市部で大気中濃度の高いのが特徵 である。これは都市部で農薬粒子が付着すると考えられ る浮遊媒じん(麼)粒子の多いことや, 衛生用殺虫鼡の使 用量の多いことが原因であろらと考えられている。

さて, 農薬散布によってかえって労働過重となってい る問題に, 果樹園における花粉媒介こん虫（ポリネータ 一）の死滅がある。大量の農薬散布によって天敵ととも に花粉媒介こん虫を导殺してしまい，代わりに人閒が人 工受粉をしなけ礼ばならなくなってしまったという大変 深刻な問題がある。

\section{5 果実・野菜における農薬の残留}

果樹や茶などの永年作物における農薬の散布回数は, 稲などの普及作物に比べるとはるかに多い，そして一般 的には調理加工をしないで生食するものの方が農薬の残 留はより大きな問題となる。

ブドウの埃合, 果奏類の中では単位重量当たりの表面 積が広く、リンニ゙やナシなどに比べて残留量が高く、ま た日数経過による減少も緩慢であるのが特徵である。

また野菜類では，葉菜類の白菜やレタスなどのように 上部が開き，葉と葉の間に薬剤の入りやすいものは他の 作物に比心゙て残留量が高くなる傾向がある。しかし，作

蔆-7 リンゴ園における農薬散布暦の一例* （○印は散布を示す）

\begin{tabular}{|c|c|c|c|c|c|}
\hline & 時 & |殺菌剂 & 殺虫剂 & $\begin{array}{l}\text { 殺ダニ } \\
\text { 剂 }\end{array}$ & $\begin{array}{l}\text { 落果防 } \\
\text { 㓮 }\end{array}$ \\
\hline 1 & 発 芽 10 日 前 & 0 & $x$ & $x$ & $x$ \\
\hline 2 & 芽出乙 2 週間後 & $\bigcirc$ & O & $x$ & $x$ \\
\hline 3 & 開＼cjkstart花 & 0 & O & $x$ & $x$ \\
\hline 4 & 直 & 0 & 0 & $x$ & $x$ \\
\hline 5 & 落 花 10 日 後 & $x$ & O & $x$ & $x$ \\
\hline 6 & 落 花 20 日 後 & $x$ & O & $x$ & $x$ \\
\hline 7 & 落 花 30 日 後 & 0 & $\bigcirc$ & $x$ & $x$ \\
\hline 8 & 前回散布より 10 日 後 & O & O & O & $x$ \\
\hline 9 & 前回散布より 2 週間後 & $x$ & $\bigcirc$ & $x$ & $x$ \\
\hline 10 & 前回散布より 2 週間後 & O & $\bigcirc$ & $x$ & $x$ \\
\hline 11 & 前回散布より 2 週間後 & 0 & 0 & $x$ & $x$ \\
\hline 12 & 前回散布より 2 週間後 & O & O & $x$ & $x$ \\
\hline 13 & 収 & $x$ & $x$ & $x$ & O \\
\hline
\end{tabular}

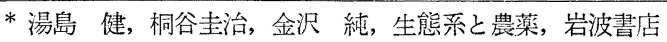
(1973) p. 78

表-8 玄米中の殘 留農薬の分布*

\begin{tabular}{|c|c|c|}
\hline 農 薬 & \multicolumn{2}{|c|}{$\begin{array}{l}\infty 2 か \text { 白米 } \\
(\%)(\%)\end{array}$} \\
\hline$p, p^{\prime}-\mathrm{DDT}$ & 70 & 30 \\
\hline$\gamma-\mathrm{BHC}$ & 40 & 60 \\
\hline マラチオン & 87 & 13 \\
\hline EPN & 80 & 20 \\
\hline ダイシストン & 65 & 35 \\
\hline バイジット & 94 & 6 \\
\hline BPMC & 80 & 20 \\
\hline CPMC & 80 & 20 \\
\hline PMA & 40 & 60 \\
\hline C P A & 40 & 60 \\
\hline
\end{tabular}

* 金沢 純, 農薬生産 技術, 25, 18 (1971)

物によってその部位に残留する量は異なり，玄米の場 合，ぬかと白米の部分に残留する量はそれぞれの部位の 脂肪含量の違いから差があり，70〜80\%はぬか部に存在 する。また, 果実においては, 浸透性の低い農薬の場合 90 \%以上が果皮の部分に存在するが，カーバメート剤や有 機リン剤の一部のものは比較的果肉部に浸透しやすく, 特に有機リン剂では酸化代謝物の浸透性が高くなる。

次に畑作物の種類による, 土壌中農薬の吸収量の違い を見てみると，地下部を食用とするものと，豆類の吸収 率の高いことが特徴である。また脂溶性の高い有機塩素 剤などはラッカセイなど油糧種子作物に大変多く蓄積 し, 土壌中の残留量の $3 \sim 4$ 倍に達することもある。

\section{6 露地栽培とハウス栽唔による残留量の違い}

近年野菜生産は新しい栽培技術の開発および園芸資材 の発達などによって, 栽培適地の拡大とともに周年供給 化の傾向にある。産地銘柄の確保と市場性の向上をはか ることが重視され, 施設の大型化, 固定化が多くなって 
きており，それに伴いかなり長期にわたって連作される 固場が多くなっている。このことは必然的に土袞伝染性 病害の多発につながり, 連作障害の中に占める土鎄病害 の役割が重大化してきている。一般にハウス内は光線不 足になり, かつ密閉による換気不良, 更には過湿の状態 になりやすく，作物の耐病性の低下により，露地栽培に 比へて病気がきわめて発生しやすい条件下におかれてい る。このことは必然的に農薬散布量の増大につながり, それにともない農薬残留量も多くなるという大きな問題 を内在している。

\section{7 農薬の分解}

土壤中からの農薬の消失については, 大気中への気 化, 地下浸透, 土壇微生物の作用, 酸化, 加水分解な ぞ，生物学的作用によるものと，物理化学的作用による ものが考えられる。

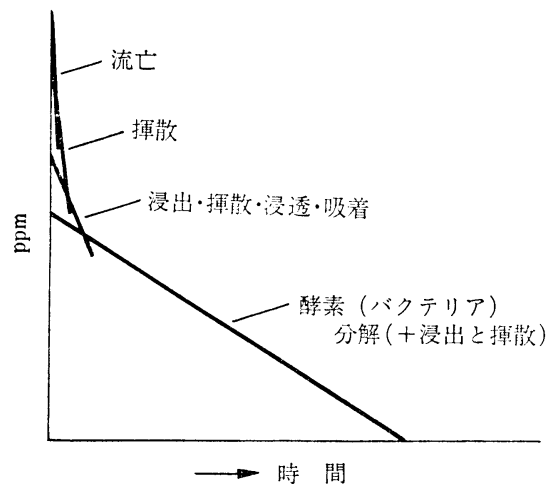

図-5 土溒中における殺虫剂の分解のパターン (エドワーズ, 1969)

アルドリン，ディルドリン，エンドリンなどシクロジ エン戍は消失速度がきわめて遅く, そのため一たん土壌 がこれらによって污染されると，長期間にわたってそこ で裁培された作物を污染していくことになる。

土㙵中での農薬の分布は化合物の溶解度と大きく関倸 するが，深度 $20 \mathrm{~cm}$ までの表層土に $80 \%$ 以上が分布して いるといわれる。

過去日本で最も大量に使用された農薬の一つである， $r-B H C$ (リンデン) についてその土壤中での分解を調べ てみると, 水田湛水状態では畑地状態に比べてはるかに 分解が速く，数週間以内で $90 \%$ 以上消失する。

土㙵中での農薬の分解には微生物の果たす役割がきわ めて大きい。

$\gamma$-BHC を混入した土壤を嫌気的条件下に㧍くと, 次 第に分解していくとともに, 一部が $\alpha-\mathrm{BHC}$ と $\delta-\mathrm{BHC}$ 一異性化する。このことから水田土壤中に残留する BHC 異性体の比率は BHC 工業用原体組成（ $\alpha: 68 \sim 78 \%$, $\beta: 9 \%, \gamma: 13 \sim 15 \%, \delta: 8 \%)$ に比へて慢性毒性の強い

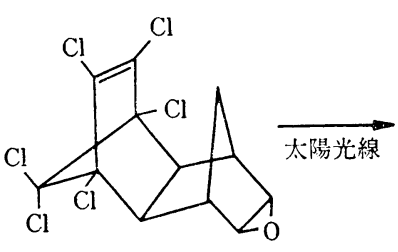

ディルドリン

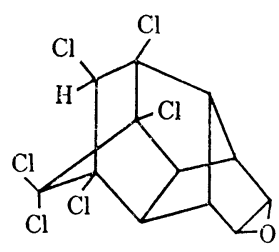

フォトディルドリン
図-6ディルドリンの光分解

表-10 環状ジェン郕とその光分解物の水生動物こ効する $50 \%$ 致死量 $(\mathrm{ppm}) *$

\begin{tabular}{|c|c|c|c|c|}
\hline \multirow{2}{*}{ 殺虫剂 } & \multicolumn{3}{|c|}{ 魚 } & \multirow{2}{*}{$\frac{\text { こえ虫 }}{\text { 力 }}$} \\
\hline & $\begin{array}{l}\text { ブルーギ } \\
\text { ル }\end{array}$ & ミノー & Asillus & \\
\hline アルドリン & 0.26 & 一 & 0.08 & 0.003 \\
\hline フォトアルドリン & 0.09 & - & 0.04 & 0.0005 \\
\hline ディルドリン & 0.17 & 0.024 & - & 0.006 \\
\hline フォトディルドリン & 0.03 & 0.010 & - & 0.003 \\
\hline ヘプタクロル & - & 0.013 & 0.10 & 0.005 \\
\hline フォトヘプタクロル & - & 0.008 & 0.06 & 0.002 \\
\hline イソドリン & 0.012 & - & - & 0.019 \\
\hline フォトイソドリン & 0.025 & - & - & 0.058 \\
\hline エンドリン & 0.010 & - & - & 0.017 \\
\hline
\end{tabular}

* E. Georgacakis, M.A.Q. Khan, Nature, 233 (1971)

$\beta-B H C の$ 比率多增加している。

土壤中の農薬はいろいろな径路汇上っ下分解消失して いくわけで岁るが，中間物も气礼ぞれに毒性を有してい るわけであり，元の化合物ぶ分解したからといって洪し て無毒化されたことにはならない。その例として，太陽 光線によってディルドリンから生ずるフォトディルドリ ンを亦げることができる。ディルドリンはアルドリンの 代謝物でもあるが，それが太陽光線壱受けることによ。 て生ずるフォトディルドリンは元の化合物のディルドり ンに比べて化学的汇はるかに安定であり, 毒性もかなり 強くなる。

\section{8 畜産製品の污染}

家畜類が農薬によって污染を受ける経路としては 1)

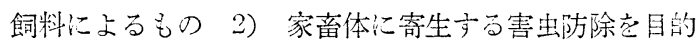
として散布された農薬や薬浴汇よるものなどがある。牛 乳の $B H C$ 污染を調べた結果では, 大体 $0.1 \mathrm{ppm}$ から

表-11 1969年採取牛乳中の $\mathrm{BHC}^{*}$

\begin{tabular}{cc|c|c|c|c|c}
\hline \multirow{2}{*}{ 採取地 } & \multicolumn{5}{|c|}{ B HC 異性体 (ppm) } \\
\cline { 3 - 7 } & & $\alpha-$ & $\beta-$ & $\gamma-$ & $\delta-$ & 全 \\
\hline 仙 & 台 & 0.059 & 0.129 & 0.003 & 0.008 & 0.199 \\
東 & 景 & 0.022 & 0.033 & 0.002 & 0.002 & 0.059 \\
大 & 饭 & 0.078 & 0.140 & 0.005 & 0.011 & 0.234 \\
高 & 知 & 0.066 & 0.220 & 0.006 & 0.011 & 0.303 \\
宮 & 䗁 & 0.097 & 0.236 & 0.007 & 0.016 & 0.356 \\
\hline
\end{tabular}

*石井象二郎, “害虫との戦い”, 大日本図書 (1974) p. 166 
表-12 DDT 添加飼料の連続給与による牛乳中への移行*

\begin{tabular}{c|c|c|c|c|c|c}
\hline 添加量 & \multicolumn{2}{|c|}{$0.5 \mathrm{ppm}$} & \multicolumn{2}{c|}{$2.0 \mathrm{ppm}$} & \multicolumn{2}{c}{$5.0 \mathrm{ppm}$} \\
\hline 日 数 & $\begin{array}{c}\mathrm{J} \\
(\mathrm{ppm})\end{array}$ & $\begin{array}{c}\mathrm{H} \\
(\mathrm{ppm})\end{array}$ & $\begin{array}{c}\mathrm{J} \\
(\mathrm{ppm})\end{array}$ & $\begin{array}{c}\mathrm{H} \\
(\mathrm{ppm})\end{array}$ & $\begin{array}{c}\mathrm{J} \\
(\mathrm{ppm})\end{array}$ & $\begin{array}{c}\mathrm{H} \\
(\mathrm{ppm})\end{array}$ \\
\hline 0 & 0 & 0 & 0 & 0.01 & 0 & 0 \\
2 & 0 & 0 & 0.01 & 0.05 & 0.16 & 0.02 \\
7 & 0 & 0 & 0.03 & 0.01 & 0.32 & 0.08 \\
12 & 0 & 0 & 0.06 & 0.03 & 0.22 & 0.07 \\
19 & 0 & 0 & 0.05 & 0.02 & 0.18 & 0.09 \\
24 & 0 & 0 & 0.04 & 0.02 & 0.20 & 0.10 \\
31 & 0 & 0.01 & 0.05 & 0.05 & 0.21 & 0.10 \\
\hline
\end{tabular}

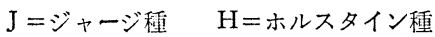

* Z.G. Smith et al., J. Agr. Food Chem., 9, 481 (1961)

$1 \mathrm{ppm}$ となっており, 北海道, 東北では $0.1 \mathrm{ppm}$ 以下 で西日本へ行くに従って増加している。これはその地域 で水稲に使用された BHC剂の使用量とほぼ比例してお り，粗飼料として給与された稲りラがその污染源であろ うと考えられる。また同じ乳牛でもホルスタイン種とジ ャージー種を比べてみると, 乳脂肪含量の高いジャージ 一種で污染が高くなっている。また食肉についてみる と, 牛肉の活染が最も高く, 次いで鷂肉となり, 豚肉は これらの中では低くなっている。これは給与される餌の 違、によるものであらう。これらの畜産物における残留 農薬污染の特徴は, 体内濃縮は急激におこるが, 逆に消 失がきわめて緩慢なことである。

\section{9 鳥類の污染}

鳥類が散布された農薬によって直接死んだり，あるい 湌物連鎖により，活染されたえさを食べてその数が減 少した例が数多くある。詳しい調查によって, 親鳥が自分 の卵を食べたり，踏みつぶしたり，あるいは卵を巣の外 に放り出したりなどという異常行動をすることがわかっ てきた。これと同時に, 卵款が薄くなり抱卵中に大変わ れやすくなっていることもわかってきた。そしてこれら 鳥類の異常が有機塩素系殺虫剤の使用量の増加之哚く関 連していることも判明してきた。その後生理学的な面か ら詳細な研究が行われ，(1)鳥類のカルシウム代謝特に卵 殼形成はエストロゲン, 甲状腺および副甲状腺ホルモン によって支配されている (2)肝臟のミクロソーム酵素は いろいるな物質を加水分解するぶ，これらの物質の中に 性ホルモンのエストロゲン，テストステロン，プロゲス テロンが含まれており，この肝臓ミクロソーム酵素を活 性化する物質の一つとして有機塩素系殺出剤がある (3)

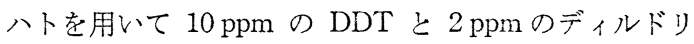
ンをえさに混ぜて 1 週間与え,プロゲステロン,テストス テロンに及ぼす作用について調查したところ，八トの肝 臟はテストステロンもプロゲステロンも分解する力が無 処理のものに比べてはるかに強いことがわかった。この 一連の結果から，鳥類の減少の原因に有機塩素系殺虫削

表-13 乳肉製品中の有機塩素系殺虫刋検出量 ${ }^{1) *}$

\begin{tabular}{|c|c|c|c|c|c|c|c|c|c|c|c|c|c|c|}
\hline 試 & 料 & 数 & $\begin{array}{l}\alpha- \\
\text { BHC }\end{array}$ & ${ }_{\mathrm{BHC}}$ & $\stackrel{\gamma-}{\mathrm{BHC}}$ & $\begin{array}{l}\delta- \\
\mathrm{BHC}\end{array}$ & $\mathrm{B}$ 全 $\mathrm{C}$ & DDE & DDD & DDT & $\mathrm{D}$ 全 $\mathrm{T}$ & $\begin{array}{l}\text { ディル } \\
\text { ドリン }\end{array}$ & $\begin{array}{l}\text { エンド } \\
\text { リン }\end{array}$ & $\begin{array}{l}\text { ヘプタク } \\
\text { ロルエボ } \\
\text { キシド }\end{array}$ \\
\hline 闈製米 & 乳 & 4 & 0.18 & 0.27 & 0.09 & 0.01 & 0.55 & 0.09 & 0.18 & 0.21 & 0.48 & 0.02 & $\operatorname{Tr}$ & 0.01 \\
\hline f - & ズ & 10 & 0.11 & 0.09 & 0.05 & 0.00 & 0.25 & 0.28 & 0.13 & 0.16 & 0.57 & 0.03 & $\operatorname{Tr}$ & 0.00 \\
\hline バ タ & - & 10 & 0.89 & 1.40 & 0.07 & 0.07 & 2.43 & 0.28 & 0.52 & 0.66 & 1.46 & 0.09 & 0.04 & 0.03 \\
\hline 牛 & 肉 & 10 & 4.60 & 8.22 & 0.46 & 0.40 & 13.68 & 0.15 & 0.06 & 0.34 & 0.55 & 0.25 & nd & ND \\
\hline 鵎 & 肉 & 10 & 0.36 & 0.73 & 0.12 & 0.14 & 1.35 & 0.27 & Tr. & 0.29 & 0.56 & 0.18 & $\operatorname{Tr}$ & ND \\
\hline 豚 & 肉 & 10 & 0.10 & 0.39 & 0.01 & nd & 0.50 & 0.16 & Tr. & 0.13 & 0.29 & 0.01 & $\mathrm{ND}$ & ND \\
\hline 鶏 & 卵 & 10 & 0.01 & 0.00 & 0.00 & 0.00 & 0.01 & 0.04 & ND & 0.03 & 0.07 & 0.01 & ND & ND \\
\hline
\end{tabular}

1）粗脂肪に対する ppm Tr.：こえ跡 ND：検出せず

* M. Uyeta et al., J. Food Hyg. Soc., 11, 256 (1970)

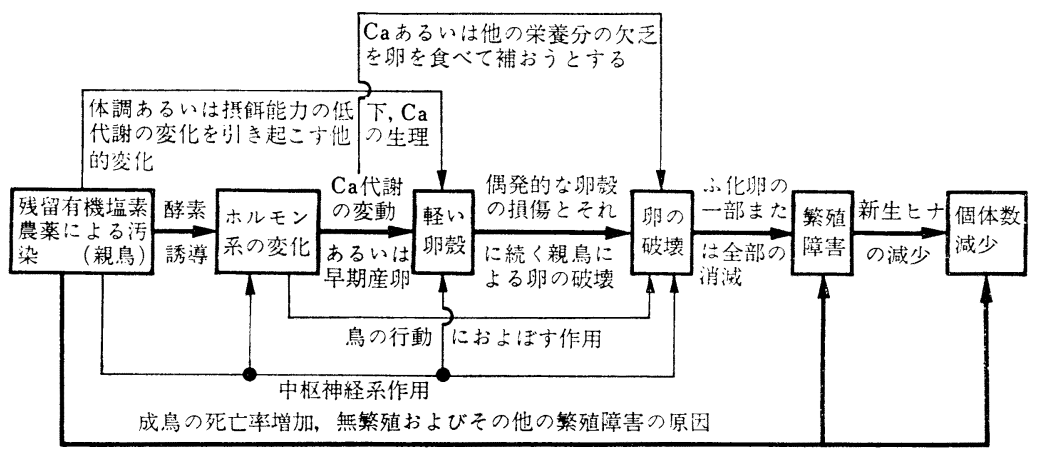

図-7 有機塩素系残留農薬によって起こる因果関係の模式図

太い矢印は強い因果関係, 細い矢印は論理的に可能な因果関倸を示す(Ratcliffe, 1970) 
表-14 DDTおよびディルドリンをハトに与えた場合 のステロイド代謝の増加*

\begin{tabular}{|c|c|c|}
\hline \multirow{2}{*}{ 基 } & \multicolumn{2}{|c|}{ 代謝された極性物質の量 $(\mathrm{m} \mu \mathrm{mol})$} \\
\hline & テストステロン & プロゲステロン \\
\hline 理 & $28.7 \pm 4.7(8)$ & $30.1 \pm 8.4(8)$ \\
\hline DDT & $75.4 \pm 18.0(6)$ & $78.3 \pm 8.4(6)$ \\
\hline ディルドリン & $111.4 \pm 12.7(6)$ & $90.3 \pm 6.1(6)$ \\
\hline DDT+ディルドリン & $168.2 \pm 9.9(4)$ & $155.4 \pm 17.8(4)$ \\
\hline
\end{tabular}

( ) 内注実験数

* D.B. Peakall, Nature, 216, 505 (1967)

が大きく関与していることがわかった。このような現象 はラットにおいても認められ, 出産前の妊娠ラットに 2 週間 $50 \mathrm{ppm}$ と $100 \mathrm{ppm}$ の DDT を含むえさを与えて 調べたところ， 50 ppm の DDT を与えたグループは他 の 2 つのグループに比べその子を食う場合が多く，また 乳を与えることも少なかったといら。また $100 \mathrm{ppm} の$ えさを与えた親から生まれた子は発育が恶く, 神経系の 発達も要いと思われるということが報等されている6。

\section{0 人体の污染}

有機塩素系秌虫剤梳世界的に広く使用された結果，世 界中の人々の体脂肪中に有機塩素系殺虫剂およびその代 謝物の蓄積が認的られている。この中で日本人の場合， 全 BHC の蓄積が高く, 2 12 ppm でこの中でも慢性 毒性の高、 $\beta-B H C$ の蓄積量の最も大きいのが特徴であ る。このような人体の農薬污染で最も重大なことは母乳 の污染である。これ関しては大阪衛研の樫本ら の的 ズミを用いて行った実験がある。それによると, 出産前 36日から 3 日間隔で一定量の BHC を親ネズミに投与し たところ，親ネズミには総投与量の $11.3 \%$ が蓄積され
表-16 母乳.中の有機塩素剂残留量* （全乳当たりの $\mathrm{ppm}$ )

\begin{tabular}{|c|c|c|c|c|}
\hline & & $\begin{array}{ll}\text { 総 } & \text { 数 } \\
(454 & \text { 例 })\end{array}$ & $\begin{array}{ll}\text { 農 } & \text { 婦 } \\
(213 & \text { 例) }\end{array}$ & $\begin{array}{l}\text { 韭豊婦 } \\
\text { (241 例) }\end{array}$ \\
\hline 総 BHC & $\begin{array}{l}\text { 最高 值 } \\
\text { 平均值 }\end{array}$ & $\begin{array}{l}1.690 \\
0.1258\end{array}$ & 0.0989 & 0.1496 \\
\hline$\alpha-\mathrm{BHC}$ & $\begin{array}{l}\text { 最高值 } \\
\text { 平均值 }\end{array}$ & $\begin{array}{l}0.016 \\
0.0031\end{array}$ & 0.0930 & 0.0031 \\
\hline$\beta-\mathrm{BHC}$ & 最高值 & $\begin{array}{l}1.158 \\
0.1200\end{array}$ & 0.0930 & 0.1438 \\
\hline$\gamma-\mathrm{BHC}$ & $\begin{array}{l}\text { 最高侐 } \\
\text { 平均值 }\end{array}$ & $\begin{array}{l}0.040 \\
0.0025\end{array}$ & 0.0022 & 0.0029 \\
\hline$\delta-\mathrm{BHC}$ & $\begin{array}{l}\text { 最高値 } \\
\text { 平均值 }\end{array}$ & $\begin{array}{l}0.0137 \\
0.0008\end{array}$ & 0.0008 & 0.0009 \\
\hline 総DDT & $\begin{array}{l}\text { 最高值 } \\
\text { 平均值 }\end{array}$ & $\begin{array}{l}0.466 \\
0.0607\end{array}$ & 0.0563 & 0.0635 \\
\hline ディルドリン & $\begin{array}{l}\text { 最高值 } \\
\text { 平均值 }\end{array}$ & $\begin{array}{l}0.043 \\
0.0037\end{array}$ & 0.0032 & 0.0032 \\
\hline
\end{tabular}

* 松島松翠, 植物の病気, 講談社 (厚生省) (1975) p. 163

ていたが，子ネズミには $0.7 \%$ であった。ところが出産 後 2 週間目には親ネズミには $1.4 \%$ と蓄積量が大幅に減 少しているが，子ネズミには逆に 29.3\% も蓄積される ことがわかった。これは明らかに母乳を通じて BHCが 子供俰移行したものである。このように母体に取り込ま れた農薬は母体内で濃縮をうけ，血中濃度の $2 \sim 4$ 倍の 濃度となる。そして母乳中の農薬濃度が容易に変化しな いことは，乳牛の場合と全く同じである。母乳は牛乳と ともに乳児にとって唯一の食品であるという面できわめ て大きな問題である。

\section{1 今 後の 対 策}

農薬による各種のマイナスのインパクトを少なくする

表-15 人体脂肪中の有機塩素系殺虫剂検出量 $(\mathrm{ppm}) *$

\begin{tabular}{|c|c|c|c|c|c|c|c|c|c|c|c|c|c|c|}
\hline \multicolumn{3}{|c|}{ 国 } & 数 & $\begin{array}{l}p, p^{\prime}- \\
\mathrm{DDE}\end{array}$ & $\begin{array}{l}\text { DDT } \\
+ \\
\text { 類縁物 }\end{array}$ & $\begin{array}{l}\alpha- \\
\mathrm{BHC}\end{array}$ & $\left|\begin{array}{l}3- \\
\mathrm{BHC}\end{array}\right|$ & $\stackrel{\gamma-}{\mathrm{B} H \mathrm{C}}$ & $\mathrm{B}$ 全 $\mathrm{H}$ & $\begin{array}{l}\text { アルドリ } \\
\text { ン十ディ } \\
\text { ルドリン }\end{array}$ & $\mid \begin{array}{l}\text { プタクロ } \\
\text { ル十同エポ } \\
\text { キシド }\end{array}$ & 測 & 定 & 者 \\
\hline \multirow[t]{3}{*}{ 1 } & \multirow{3}{*}{  } & リ ス & 66 & 2.0 & 3.1 & & & \multirow{3}{*}{$\begin{array}{l}0.34 \\
0.16\end{array}$} & & 0.21 & Tr. & \\
\hline & & 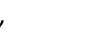 & 101 & 1.5 & 2.6 & & & & & 0.23 & 一 & \multicolumn{3}{|c|}{ Cassidy et al. (1967) } \\
\hline & & " & 16 & 4.5 & 6.0 & & & & & 0.27 & - & \multicolumn{3}{|c|}{ Robinson (1969) } \\
\hline オ & ラ & ダ & 11 & 1.7 & 2.0 & & & \multirow[t]{2}{*}{0.10} & & 0.17 & 0.009 & \multicolumn{3}{|c|}{ Vlieger (1968) } \\
\hline フ & ラ & ス & 10 & 3.2 & 5.2 & & & & & & & \multicolumn{3}{|c|}{ Hayes et al. (1963) } \\
\hline 1 & タ & ア & 22 & 7.5 & 8.2 & & & \multirow[t]{2}{*}{0.06} & & 0.45 & 0.21 & \multicolumn{3}{|c|}{ Vecchio \& Leoni (1967) } \\
\hline 1 & ス ラ & ル & 133 & 9.9 & 8.2 & & & & & & & \multicolumn{3}{|c|}{ Wasserman et al. (1967) } \\
\hline 1 & ン & ド & 24 & 11.6 & 27.8 & & & 1.7 & & 0.03 & & \multicolumn{3}{|c|}{ Dale et al. (1965) } \\
\hline & ージー & ノド & 52 & 3.8 & 5.3 & & & $\operatorname{Tr}$. & & 0.27 & & \multirow{2}{*}{\multicolumn{3}{|c|}{$\begin{array}{l}\text { Brewerton \& McGrath (1967) } \\
\text { Bick (1967) }\end{array}$}} \\
\hline オ & ースト & & 53 & 0.93 & 1.7 & & & & & 0.05 & & & & \\
\hline \multirow[t]{3}{*}{ 丁 } & $x$ & カ & 25 & 6.85 & 10.0 & & & 0.06 & & 0.29 & 0.24 & \multicolumn{3}{|c|}{ Hayes et al. (1965) } \\
\hline & " & & 42 & 6.7 & 9.8 & & & & & 0.22 & & \multirow{2}{*}{\multicolumn{3}{|c|}{$\begin{array}{l}\text { Fiserova-Bergerova et al. (1967) } \\
\text { Edmundson et al. (1968) }\end{array}$}} \\
\hline & " & & 146 & 7.0 & 10.3 & & & & & 0.22 & & & & \\
\hline カ & ナ & ダ & 47 & 2.66 & 4.0 & & & 0.06 & & 0.16 & 0.07 & \multicolumn{3}{|c|}{ Brown (1967) } \\
\hline \multirow[t]{2}{*}{ 日 } & & 本 & 74 & 4.57 & 2.35 & 0.25 & 11.86 & 0.07 & 12.17 & 0.46 & 0.01 & \multicolumn{3}{|l|}{ 西本ら (1970) } \\
\hline & " & & 6 & 2.63 & 1.20 & 0.18 & 2.09 & 0.24 & 269 & & & \multicolumn{3}{|c|}{ 福田, 楢府(1970) } \\
\hline
\end{tabular}

* 湯嶋 健, 桐谷圭治, 金沢 純, 科学, 41 (9), 514 (1971) 
ために注，農薬使用量を隇らすことであり，それに代わ って各種の病害虫・雑草防除手段を相互に相乗的に作用 するような技術の確立をはかることである。それに関す るいくつかの個々の事例を列記する。

\section{$11 \cdot 1$ 害虫の防除}

\section{$11 \cdot 1 \cdot 1$ 天敵の利用}

アメリカにおいてイセリヤカイガラムシ（かんきつ害 虫) 駆除にオーストラリアからベダリアテントウムシを 導入して駆除に成功した。こ兄が各国の研究に拍車をか けることになり，わが国でもべダリアテントウムシは大 きな役割を果たした。わが国の天敵利用の成功例として は,ミカントゲコナジラミに対するシルベストリコバチ, ルビーロウカイガラムシに対するルビーアカヤドリコバ テ (ミカントゲコナジラミ, ルビーロウカイガラムシと 品幼虫期汇ミカンなどかんきつの葉に寄生し, 汁液を吸 收するた方，樹勢が著しく衰える。また幼虫はいずれも 㮫分を含む液を分泌するためスス病が発生し, その被害 を一層大きくする)，リンゴノメンチュウをメンチュウ ヤドリコバチで防除成功した 4 例がある。このような 導人天敵の㴗方に在来天敵も多数打り, これら天敵類の 生息場所を確保し, 增殖させるために一時的汇害虫を放 飼する場合も宓る。今までの例は寄生ばちや捕食性天敵 を利用する例であるが，微生物やウィルスを用いて害虫 を防除する方法もある。微生物天敵としてはバチルス・ チューリンギエンシスと呼ばれる細菌を培養し, 芽胞を 生産して利用する技術に高い関心が寄せられている。一 方こん虫汇寄生するウィルスでは多角体ウィルスを利用 して害虫を防除することが試みられている。

\section{$11 \cdot 1 \cdot 2$ 抵抗性品種の利用}

害虫汇槣主として非常に適した植物から, あまり適 していない植物まで大きな差があり, また品種間でもし (嘹)好の差がある。ある品種は害虫に対して免疫性と思 われるものも㐫り，このような害虫に対して抵抗性の強 い品種を用いれば，被害を回避するか又は少なくするこ とができる。代表的なものとしては, クリタマバチ抵抗 性の栗, フィロキセラ (アブラムシの一種) とブドウ

(フィロキセラ免疫性の野生ブドウを台木として接木す ることによって免瘵性を獲得させる) などがある。

\section{$11 \cdot 1 \cdot 3$ 害虫の不妊化}

雄を放射線照射などの方法によって不妊化して，害虫 の撲滅をはからうとする方法である。ベネズエラ沿岸の キュラソー島で家畜の大害虫ラセンウジバエを防除する ために応用され，半年後にはこの島からラセンウジバエ を完全に防除することに成功した。この不妊化法は島な どの隔離された条件下で，しかも害虫密度が比較的低い 場合に成功する可能性がある。日本でも沖縄県のウリミ バエの防除をこの方法で行う事業が現在㝘施されている

$11 \cdot 1 \cdot 4$ 性誘引物質, 誘引物質
これらの誘引作用を有する物質を利用して害虫を集め て防除しようとする方法である。

\section{$11 \cdot 2$ 植物病害防除法}

$11 \cdot 2 \cdot 1$ 弱毒ウィルスの利用

トマトのモザイク病に対して弱毒ウィルスを接種して 病気を予防しようとする試みが行われている。ある植物 がウィルスに感染すると, 後から別のウィルスの感染が おこらないといら現象 (交叉免疫)を利用したものであ る。したがって大きな被害をもたらすウィルス病の流行 が予測される場合, あらかじめ市まり害のない別のウィ ルスに感染させておくことによって予防しようとする方 法である。

\section{$11 \cdot 2 \cdot 2$ ファイトアレキシンの利用}

植物が病原菌の感染をうけると, そ机安で健全な植物 には含まれていなかった抗菌性物質が生成する。この抗 菌性物質をファイトアレキシンといら。この現象を利用 して, あらかじめ植物にファイトアレキシンをつくらせ ておき, 後から侵入してくる病原菌が植物組織内で広が るのを抑える方法である。

表-17 現在までに明ら次にされたフォイトアレキシン*

\begin{tabular}{|c|c|}
\hline ファイトアレキシン名 & 植 物 名 \\
\hline $\begin{array}{c}\text { テルペノイド類 } \\
\text { イポメアマロン } \\
\text { リシチン } \\
\text { カプシドール } \\
\text { エ゙シポール } \\
\text { バーゴシン }\end{array}$ & $\begin{array}{l}\text { サッマイモ } \\
\text { ジャガイモ } \\
\text { シマトウガラシ } \\
\text { ワ タ } \\
\quad \text { " }\end{array}$ \\
\hline $\begin{array}{c}\text { イソフラボノイド類 } \\
\text { ピサチン } \\
\text { ファゼオリン } \\
\text { トリホリジン } \\
\text { メジカルピン } \\
\text { クメステロール }\end{array}$ & $\begin{array}{l}\text { エンドウ } \\
\text { インゲン } \\
\text { 赤クローバ } \\
\text { アルファルフォ } \\
\quad \text { " }\end{array}$ \\
\hline $\begin{array}{l}\text { イソクマリン・フラノクマリン類 } \\
\text { 6-メチルメレイン } \\
\text { 4,5,8-トリメチル・スポラレン } \\
\text { スニポレチン } \\
\text { ウムベロフェロン }\end{array}$ & $\begin{array}{l}\text { ニンジン } \\
\text { セロリー } \\
\text { サツマイモ } \\
\quad \quad "\end{array}$ \\
\hline $\begin{array}{c}\text { フェノール化合物質 } \\
\text { オルキノール } \\
\text { ピノシルビン } \\
\text { ワィアロン }\end{array}$ & $\begin{array}{lll}\text { ラ } & & \text { V } \\
\text { マ } & & \text { ッ } \\
\text { サ } & \text { サ } & \text { ゲ }\end{array}$ \\
\hline
\end{tabular}

*酒井隆太郎“植物の病気”講談社 (1975) p. 163

$11 \cdot 2 \cdot 3$ インターフェロン

ファイトアレキシンがカビの感染でっくられるよう に, ウィルスの感染によって生ずる抗ウィルス性物質で ある。のほかに病害抵抗性品種の利用も当然含まれる。

以上のような技術はいずれも研究が始められたばかり であるが将来植物病害の予防・治療媇しい局面を開く 
ことが期待される。

\section{$11 \cdot 3$ 土壤病害の生物的防除について}

土壤殺菌剤は普通の散布剤に比べて大量投入を要する ことが多く，いろいろな面で危険性も一層大きくなる。 従って薬剤防除以外に抵抗性品種の利用や, 生態的防除 法の技術を利用することが重要である。生態的防除法と しては(1)連作をさけ輪作体系とする：稲を例外として, 普通の作物は土㙥病害を防ぐほか, 土壌を良好な状態に 保持する上から連作はさけるべきである。例えば小麦の 立枯病は小麦一野菜一小麦と輪作する場合にはかなり発 病を防ぐことができる。また土壤病原菌のフザリウム， リゾクトニア，根こぶ病原菌などは土の中で 2 5 年間 生存するので, 短期間の輪作では発病を防止することが できない。そのために例えば奈良県などではスイカ，マ クワウリの畑作と水田との組み合わせで作付年限を 5 年 以上へだてることでつるわれ病の発病を抑えている。

(2)有機物の施用：消石灰の多量施用は土壤中の病原菌 数を少なくし，その結果発病もきわめて軽くなる。また 消石灰多量施用之有機物施用を組み合わせると，消石灰 多量施用による害作用は軽減され，また発病抑制効果も 長期間持続することが認められた。キチンは非常に多く の放線菌と細菌の一部によって特異的に利用される物質 であるといわれている。キチン（カニ款など）を土壌に 添加することによって, 放線菌が爆発的に増加し, 細菌 もまた増加する。これに伴い, 土壤中のキチナーゼ生産 菌が増加し，土壌のキチナーゼ活性の高まりがみられた

表-18 Fusarium solani $f$. phaseoli によるインゲ ン根腐病に対するキチン添加の効果

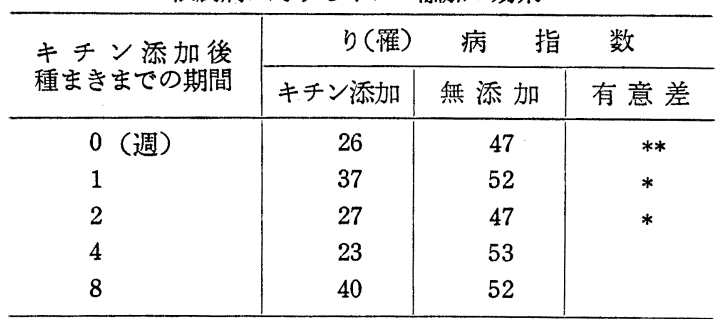

*,**それぞれ，5\%，1\% 水準で意意差あり

1) R. Mitchel et al., Soil Sci.Soc. Am. Proc., 26, 556 (1962)

表-19 キチン添加による微生物数の変化 ${ }^{1)}$

\begin{tabular}{|c|c|c|c|c|c|c|}
\hline \multirow{3}{*}{$\begin{array}{l}\text { キチン添加後 } \\
\text { 種まきまでの } \\
\text { 期間 }\end{array}$} & \multicolumn{6}{|c|}{ 乾土 $g$ 当たり菌数 $\times 10^{8}$} \\
\hline & \multicolumn{2}{|c|}{ 糸 状 菌 } & \multicolumn{2}{|c|}{ 放 線 菌 } & \multicolumn{2}{|l|}{ 細 } \\
\hline & $\begin{array}{l}\text { キチン } \\
\text { 添加 }\end{array}$ & 無添加 & $\begin{array}{l}\text { キチン } \\
\text { 添加 }\end{array}$ & 無添加 & $\begin{array}{l}\text { キチン } \\
\text { 添加 }\end{array}$ & 無添加 \\
\hline 0 & 33 & 30 & 100 & 100 & 600 & 600 \\
\hline 1 & 12 & 32 & 700 & 210 & 1,300 & 600 \\
\hline 2 & 21 & 35 & 3,500 & 130 & 1,200 & 800 \\
\hline 4 & 34 & 29 & 2,200 & 460 & 1,300 & 1,200 \\
\hline 8 & 39 & 26 & 380 & 150 & 3,100 & 700 \\
\hline
\end{tabular}

1）表-18 と同じ

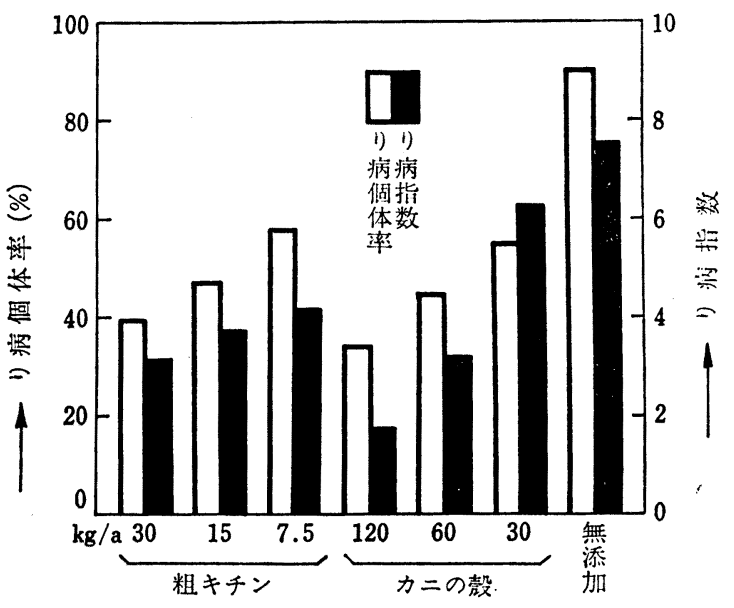

図-8 粗キチン及びカニの殻の土㙵添加によるダイコンい 黄病防除勃果（駒田ら，1965）

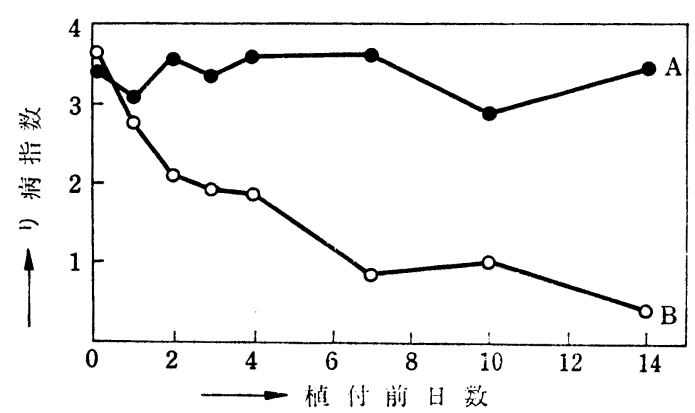

A) 無添加区 B) コーヒーかすす添加区(0.5\%, $\mathrm{wt} / \mathrm{wt}$ )

図-9 根腐病の発生に及ぼすコーヒーかす添加の影響 (Adams 1968)

ばかりか, 病原菌に対する溶菌性微生物数も增加してい る。このようなキチン添加の効果は, インゲン根腐病を はじめ, カンランい黄病, エンドウ根腐病, ダイコンい 黄病などでも認められた。このほかにもコーヒーかすの 施用がインゲン根腐病の防除に有効であることが判明し ている。また, トリコデルマ菌を培養したものをタバコ やコンニャクの株元に散布して, これらの白䅌病防除に 利用している。

\section{ま と め}

かって日本の農村では誘が登がどこへ行っても見られ たものである。しかし，今はどうであろらか。日本の農 村から誘が燈が姿を消した原因は GHQ の占領政策にあ る。誘が登はニカメイチュウを誘殺するが，その他にも 多数のこん虫類も誘殺し, その中には益虫も含まれてい るといらのが理由であった。そして誘が登の代わりに当 時農薬としてその効果が認められはじめた DDT の使用 を推し進めたのである。確かに誘が登は害虫ばかりでな く, 益虫も誘殺することは事実であるが, 飛ばないこん 
手段老用いる目的

手段のグルーブ

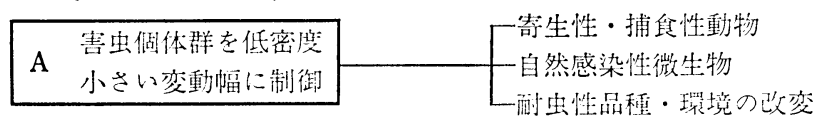
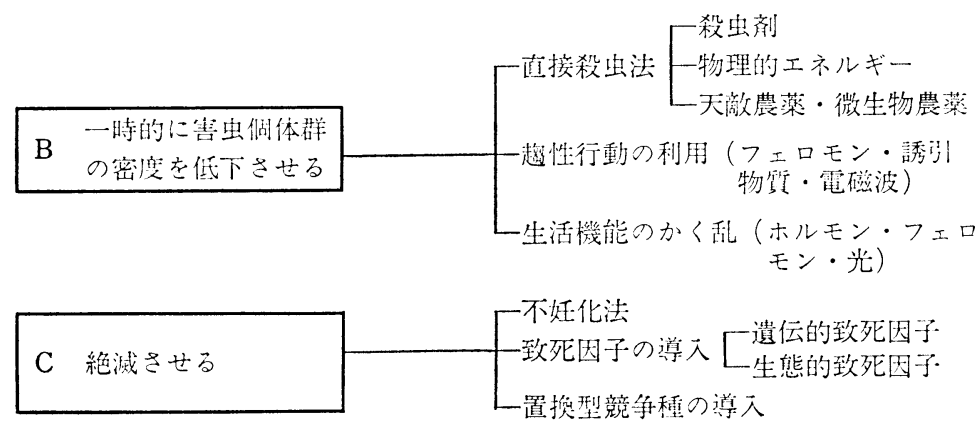

図-10 各理防除手段の整理を示す模式困（桐谷ら，1971）

表-20 高知県各地で行われた䙵薬の散布回数減少の可 能性を検討するための実験水田と慣行防除田で の防除回数と収量の比較*

\begin{tabular}{|c|c|c|c|c|c|c|c|}
\hline \multirow{2}{*}{$\begin{array}{l}\text { イネの } \\
\text { 作 期 }\end{array}$} & \multirow{2}{*}{$\begin{array}{l}\text { 畨場の } \\
\text { 䅣 類 }\end{array}$} & \multirow{2}{*}{\begin{tabular}{|l} 
直場の \\
䇫所数
\end{tabular}} & \multicolumn{4}{|c|}{ 防 除 回 数 } & \multirow{2}{*}{$\begin{array}{l}10 a \text { 当たり } \\
\text { 收量(玄米， } \\
\mathrm{kg} \text { ) }\end{array}$} \\
\hline & & & 殺虫剂 & 殺菌斉 & 除草剂 & 計 & \\
\hline \multirow[t]{2}{*}{ 早 稲 } & 実験田 & 5 & 2.0 & 3.0 & 1.4 & 6.4 & 459 \\
\hline & $\begin{array}{l}\text { 慣行防 } \\
\text { 梌田 }\end{array}$ & 15 & 3.1 & 3.7 & 1.6 & 8.4 & 433 \\
\hline \multirow[t]{2}{*}{ 音通稲 } & 実験田 & 9 & 2.0 & 3.3 & 2.4 & 7.7 & 390 \\
\hline & $\begin{array}{l}\text { 慣行防 } \\
\text { 除田 }\end{array}$ & 27 & 4.4 & 3.8 & 2.0 & 10.2 & 377 \\
\hline
\end{tabular}

* 桐谷圭治, 中筋房夫, “環境の科学”, 日本放送出版協会 (1972) p. 251

虫が誘殺されることはほとんどないのである。しかし， DDT は害虫も益虫も全く無差別に殺してしまうわけで あり，DDT が誘が燈の役割を果たすことはできないの である。このような政策がおし進妨られ背景には, 日 本の応用こん虫学者に対応するだけの充分な資料のなか

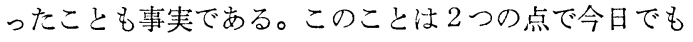
まだその流れの中にあるといえないであろらか。一つは 農薬中心のきわ奴い弱な農業技術が今もそのまま続 いていること, そして 2 番目には, 現在もまだ充分な知 識の集積がないという点で,この両者は表裏一体のもの として日本の農業の体質を象徴するものである。農薬に よって病害虫を防除することは, 多くの技術の中の単に 一手段に過ぎないのであって, それが中心であり, 最も 科学的であるという誴った認識が生態学的視野からの研 究をおくらせ，根本的には今日の状態をもたらしたもの であろう。農薬使用量を減らして環境を守り, 国民の健 康を守るためには多くのことがなされなければならな い。研究者も行政担当者も真剣にそのことを考え, 一日 も早く実行しなければならないのではなからうか。

（昭和51年 5 月 12 日受理）

\section{図の引用文献}

図-2: 桐谷圭治, 中筋房夫, “環境の科学”, 日本放送出版協会 (1972) 260.

図-3: 門司正三, “環境の科学”日本放送出版協会 p. 182 .

図- 4 : C.A. Edwards, (1970) “Critical Reviews in Environmental Control”, 1, 7 Pub. Chem. Rubber Co.

図- 5 : C.A. Edwards, J.R. Lofty (1969)“The Soil Ecosystem” (J.G. Sheavs, ed.), p. 237.

図- 6 : 湯嶋 健, 桐谷圭治, 金沢 純, “生態系と農薬” 岩波 書店 (1973) p. 66.

困- 7 : D.A. Ratcliffe, J. Appl. Ecol., 7, 167 (1970)

図-8：駒田ほか土と微生物, 7, 41 (1965)

四- 9 : P.B. Adams et al., Phytopath., 58, 1603 (1968)

図-10: 桐谷圭治, 中筋房夫, “環境の科学”, 日本放送出版協会 (1972) p. 256.

1）石井象二郎“害虫との戦い”(1974) 大日本図書

2) 桐谷圭治, 中筋房夫 “環境の科学” (1972) 日本放送出版 協会

3）酒井隆太郎 “植物の病気” (1975) 講談社

4）湯嶋 健, 桐谷圭治, 金沢 純 “生態系と農薬” (1973) 岩波・現代科学選書

5）農林省農蚕園芝局植物防疫課監修（1975）“農薬要覧”

6）金沢 純, 農業および園芸, 48, 164 (1973)

7）駒田 旦, 農業および園芸, 46, 1137 (1971)

8）檀原 宏, 畜産の研究 27, 212 (1973)

9）中川恭二郎, 農業および園芸, 48, 517 (1973)

10）鈴井孝仁, 農業小よび園芸, 46, 1269 (1971)

11）真梶徳純，農業および園芸，46，1223 (1971)

$$
\text { 文献 }
$$

1) W.E. Ripper, Ann. Rev. Entomol., 1, 403 (1956)

2) A.M. Massee, Proc. Intern. Congr. Entomol., 10 th, Montreal (1956), 3, 163 (1958)

3）桐谷圭治, 中筋房夫, 環境の科学, 日本放送出版協会 (1972) p. 248.

4) A.V. Holden, J. Appl. Ecol., 3 (Suppl.), 45 (1966)

5) J.L. George, D.E.H. Frear, J. Appl. Ecol.,(Suppl.) 3, 155 (1966)

6) 科学新聞, 1975年 6 月20日

7）樫本，朝日新聞 1972 年 5 月22日 